\title{
How much sagebrush is too much: An economic threshold analysis
}

\author{
CHRIS T. BASTIAN, JAMES I. JACOBS AND MICHAEL A. SMITH
}

Authors are assistant extension educator and professor, Agriculural Economics Department and professor, Range Management Department, respectively, University of Wyoming, Laramie, Wyo. \$2071.

\begin{abstract}
Much research concerning sagebrush control methods and forage response after control has been conducted due to the importance of sagebrush-grass dominated rangelands for livestock and wildlife in the western United States. Very little research has addressed the economic feasibility of sagebrush control at various levels of abundance. This study estimates the economic threshold abundance of sagebrush based on forage response data from a sagebrush control experiment in Carbon County, Wyo. Forage response data are based on the difference in herbage between treated and untreated experimental units from sites ranging in initial sagebrush canopy cover from 4 to $40 \%$. Breakeven returns per AUM were estimated for each sagebrush canopy cover level assuming 2,4-D (2,4-dichlorophenoxyacetic acid) or burning (for 28 to $40 \%$ canopy cover) as a control method with lives of control at 15,20 , and 25 years. These breakeven returns were compared to a net lease rate of \$6.13/AUM. Results indicate the economic threshold abundance of sagebrush is $12 \%$ assuming, 2,4-D as the control method and a control longevity of 25 years, but the feasible sagebrush abundance increases as longevity of control decreases. If the longevity of the control only lasts 20 years, the sagebrush abundance must be at least $20 \%$ before treating sagebrush becomes economically feasible. If the longevity of control is only 15 years, sagebrush abundance must be at least $24 \%$ canopy cover before treatment is economically viable. Given estimates of the cost of burning are almost half that of spraying with 2,4-D, all the scenarios which had enough biomass to sustain a burn $(28 \%$ to $40 \%)$ indicated sagebrush control by fire was economically viable.
\end{abstract}

Key Words: Artemisia tridentata ssp. wyomingensis, breakeven return per AUM, life of control, 2,4-D, and burning.

The sagebrush-grass ecosystem occupies a substantial portion of rangelands in the western United States. Acreage estimates of sagebrush-grass rangeland vary from 30 million ha to 109 million ha (Blaisdell et al. 1982). Estimates indicate that big sagebrush (Artemisia tridentata Nutt.) is the dominant range cover on approximately 39 million ha in the West (Alley 1965). Since sagebrush-grass rangelands are used predominantly to produce

Manuscript accepted 28 May 1994. forage for livestock and wildlife, sagebrush control methods, degree of control and forage response have been the subject of much research.

Research has primarily focused on control methods and forage response after control. The literature indicates burning and spraying with 2-4,D are the most successful and cost effective methods for controlling sagebrush (Kearl and Brannan 1967, Kearl 1965, Krenz 1962, Mueggler and Blaisdell 1958, Smith et al. 1985). Forage response after control varies greatly, from 0 to $400 \%$ of production on comparable uncontrolled sites, depending on such factors as precipitation, composition of understory vegetation, sagebrush mortality, method of control, grazing management after control, and density of sagebrush population before control (Alley and Bohmont 1958, Bartolome and Heady 1978, EPA 1972, Kearl and Brannan 1967, Kearl 1965, Mueggler and Blaisdell 1958, Pechanec et al. 1954, Smith and Busby 1981, Sturges 1986, Tabler 1959, Tanaka and Workman 1988, Wambolt and Payne 1986).

Information concerning control methods and forage response is important to the range manager when making sagebrush control decisions. A major problem for managers is identifying a site where (1) the infestation of sagebrush is dense enough to cause a significant reduction in forage yield and (2) the potential increase in forage production would be sufficient to economically justify the control of sagebrush (Jacobs 1987).

Early research focused on the question of proper chemical mixture and recommended percent sagebrush mortality rather than identifying economic threshold sagebrush densities. Hull et al. (1952) treated plots of sagebrush averaging 25 to 30 plants per $30.5 \mathrm{~m}^{-2}$. They used a total of 57 different herbicide and carrier mixtures in 1949 and 59 different mixtures in 1950. They concluded grass production could be increased 2 to 3 times in 2 years after chemical control of sagebrush as long as there was fair grass understory before treatment. They also concluded the increases were to some degree proportional to the percent of sagebrush plants killed. Native grass production was increased approximately 2 to 3 times by killing 60 to $97 \%$ of the sagebrush.

Alley (1956) used different rates and esters of 2,4-D and 2,4,5$T$ to better understand chemical control of sagebrush and the corresponding forage response after control in the Bighorn Mountains of Wyoming. Sagebrush clumps "averaged 26.9 inches in height by 30.0 inches in diameter and 32 clumps per square rod" (Alley, 1956). By sampling vegetation within the treated and untreated strips Alley (1956) determined the influence of various 
degrees of sagebrush control upon the grass-like species, forbs and shrubs. Data was summarized on the basis of 0,50 to 75,76 to 95 , and 96 to $100 \%$ of sagebrush control. Alley (1956) concluded native grass production was increased as control of sagebrush increased. The most grass production was observed in the 96 to $100 \%$ sagebrush controlled areas.

Miller et al. (1980) tried to document changes in forage production and plant species abundance following application of 2,4-D in three mountain big sagebrush (Artemisia tridentata ssp. vaseyana (Rydb.) Beetle) habitat types. Shrub cover varied between 21 and $33 \%$ canopy cover on the 3 habitat types. Percent mortality of sagebrush ranged between 81 and $97 \%$. Across the three habitat types bluebunch wheatgrass (Agropyron spicatum (Pursh) Scribn. and Sm.) was more responsive on the sprayed sites than Idaho fescue (Festuca idahoensis Elmer). Total forb production was lower on sprayed sites.

Whitson and Alley (1982) established experimental plots near Ten Sleep, Wyoming on sagebrush infested land to evaluate the potential of tebuthiuron $\{\mathrm{N}-[5-(1,1-$ demethylethyl)-1,3,4-thiadiazol-2-yl] -N,N'-demethylurea $\}$ as a potential chemical control method on sagebrush. Three rates of $20 \%$ granular material, 0.29 , $0.62,0.86 \mathrm{~kg} / \mathrm{ha}$ a.i. (active ingredient), were applied. Oven dry yields gathered 3 years after control from the $0,0.29,0.62$, and $0.86 \mathrm{~kg} / \mathrm{ha}$ rates were $283,351,658$, and $508 \mathrm{~kg} / \mathrm{ha}$, respectively. Sagebrush defoliation for the $0.29,0.62$, and 0.86 rates of tebuthiuron were 69,96 , and $99.5 \%$, respectively.

Clary et al. (1985) studied the effectiveness of tebuthiuron in controlling woody plants on Utah juniper (Juniperus osteosperma (Torr.) Little) and mountain big sagebrush dominated sites and evaluated responses of herbaceous species. Application rates of 0 , $0.6,1.0$, and $1.3 \mathrm{~kg} / \mathrm{ha}$ a.i. of $10 \%$ pellets was applied on the mountain big sagebrush strips. The authors found a high proportion of control at the 0.6 (approx. $80 \%$ ) rate and nearly complete control of the original sagebrush plants at the $1.3 \mathrm{~kg} / \mathrm{ha}$ rate (approx. 93\%). Total production of herbage (including leaf and twig growth on shrubs) ( $P>0.05$ ) was not significantly different from the control in the third growing season after sagebrush treatment. Fairway wheatgrass (Agropyron cristatum (L.) Gaertn.) was initially depressed, but recovered by the third year.

Hull and Klomp (1974) tried to evaluate 3 different control methods at different big sagebrush densities and how that affected, (1) yields of crested wheatgrass (Agropyron desertorum (Fisch. ex Link) Schult) growing under sagebrush, (2) amount of rain and snow reaching the soil and (3) soil moisture content. In 1950 and 1954 several sites in Idaho were cleared of sagebrush and seeded to crested wheatgrass. Big sagebrush reinvaded seeded ranges to a density of 20 plants per 30.5 meters 2 . In 1965 big sagebrush was reduced to 10,5 , and 0 plants per 30.5 meters $^{2}(50$, 75 , and $100 \%$ kills) by grubbing, burning, and spraying with $2,4-$ $D$. The authors concluded that the 3 methods of control did not differ in the amount of grass produced following brush control, and where wildlife or livestock do not need sagebrush, all the brush should be killed. Any remaining sagebrush suppresses grass and produces seed for reinvasion.

Tanaka and Workman (1988) extended Hull and Klomp's (1974) work into an economic framework developed for estimating the optimum rate of initial overstory kill for increasing seasonal forage availability. The model was formulated using, (1) biological data from Hull and Klomp (1974) to estimate a production function relating understory production to initial kill percentage, (2) a derived demand function for seasonal forage value by using linear programming to estimate shadow prices for additional production of crested wheatgrass, and (3) a cost of overstory kill function for each control method. Tanaka and Workman (1988) used the big sagebrush- crested wheatgrass vegetation type on a "typical case ranch" (cow-calf-yearling operation) in Utah. For the case ranch analyzed, a big sagebrush kill rate between 92 and $100 \%$ was optimal.

While these pieces of research tried to ascertain forage responses using different chemical mixtures, in different habitat types and different percentages of sagebrush mortality, they do not provide much information in terms of what initial sagebrush abundance level will be economically feasible to consider control. Additionally, today's managers must consider the possible environmental effects sagebrush control might have on ecosystems managed for multiple uses. These economic and environmental factors preclude a manager from indiscriminately controlling sagebrush. Managers need additional information to aid them in assessing whether sagebrush control is an economically viable alternative.

The focus of this study is to determine the economic threshold abundance level for big sagebrush control. The economic analysis in this study is based on forage response data from a study of sagebrush control in Carbon County, Wyo.

\section{Materials and Methods}

\section{Study Area}

The forage response data comes from an area in southcentral Wyoming, approximately $19 \mathrm{~km}$ northeast of Saratoga, Carbon County, Wyo. The area is on the west slope of the Medicine Bow mountain range at an elevation of $2,245 \mathrm{~m}$ and receives about 33 $\mathrm{cm}$ of precipitation annually. Vegetation in the area is dominated by an overstory of Wyoming big sagebrush (Artemisia tridentata ssp. wyomingensis Beetle and Young) with an herbaceous layer featuring western wheatgrass (Agropyron smithii Rydb.) and needle-and-thread grass (Stipa comata Trin. \& Rupr.). Forbs are not abundant in the study site.

Within this area, 20 study sites were selected across a range of big sagebrush abundances as measured by canopy cover, but on similar sandy soils and topographic positioning. On each study site 2 experimental units (approximately $30 \mathrm{~m}$ by $30 \mathrm{~m}$ each) with the same big sagebrush abundances were selected and randomly designated, one with sagebrush controlled and the other not treated. Two replicate pairs of each sagebrush abundance level were included in the design. Sites had big sagebrush canopy cover (cover was determined using 6-100 point transects) ranging from 4 to $40 \%$ in approximately equal increments.

Big sagebrush was treated by spraying with $2,4-\mathrm{D}$ in early June of $1987^{1}$. For each study site, peak standing biomass of all herbaceous vegetation has been measured in late July each year of the study by harvesting vegetation on quadrats protected by movable cages ( 6 per experimental unit). The herbaceous biomass consisted primarily (approx. 90\%) of western wheatgrass and needleand-thread grass. A small portion of the clipped herbage sometimes included annuals and forbs (approx. 10\%). All of the herbage was usable by cattle and sheep at least during part of the

'It is important to note that ground application of 2.4-D occurred in June 1987 on the study sites in Carbon County, Wyo. for the experiment used in this analysis. Sagebrush control was in excess of $95 \%$ mortality on all treated sites. 
grazing season. The difference in herbaceous biomass between the treated and untreated experimental units was assumed to be the forage response due to controlling sagebrush.

These data were adjusted for precipitation and soil moisture differences among study sites using regression analysis. While these models are linear in nature, it is important to remember that they are used to normalize the data, and they are not a simulation or production function model used to estimate production over the life of the sagebrush control. Assumptions concerning the pattern of utilization over the life of control will be discussed later in the economic analysis section of the text.

Linear regression models used to normalize the data should be fairly accurate across the sites. Sala et al. (1988) found production at the site level was largely accounted for by annual precipitation, soil water-holding capacity, and an interaction term. This simple linear model accounted for $90 \%$ of the variation in production from site to site. Sala et al. (1988) found the addition of other climatic variables such as potential evapotranspiration, temperature, or the precipitation:potential evapotranspiration ratio for the growing season or the entire year did not significantly improve the model. The more sophisticated models including such variables did not account for more than $90 \%$ of the variation in production.

The variables used to estimate the regression parameters for calculating the adjusted production data across experimental sagebrush sites for this study were percent sagebrush (sage), precipitation for April, May, and June (precip), percent May soil moisture for check plots (mayc), percent soil moisture for treated plots (mayt) and year (yr). The regression models were as follows:

\section{MODEL FOR UNTREATED CHECK PLOTS}

Yield $=B_{0}+B_{1}$ sage $+B_{2}$ precip $+B_{3}$ Mayc $+B_{4} y r+\varepsilon$

MODEL FOR TREATED PLOTS

where:

Yield $=B_{0}+B_{1}$ sage $+B_{2}$ precip $+B_{3}$ Mayt $+B_{4}$ yr $+\varepsilon$

B's = estimated regression parameters

Yield = Yield based on clip data for that year and corresponding plot

sage $=$ percent sagebrush $(4$ to 40$)$

precip = sum of precipitation collected from site gauges April, May and June for each year of study period

Maye = soil moisture for each year of study period in May on check plots

Mayt $=$ soil moisture for each year of study period in May on treated plots

yr $=\quad$ Year $(1987=-2,1988=-1,1989=0,1990=1,1991=2)$

$\varepsilon=\quad$ Error

The normalized yields were estimated by calculating the predicted yields for each year and percent sagebrush using the estimated regression parameters, mean soil moisture for the study period for both the check plots and the treated plots and mean precipitation for the months of April, May, and June during the study period. These normalized yields were designed to take out variability associated with differences in annual precipitation from year to year and differences in soil moisture across study sites, so that yield differences for each year were associated with percent of sagebrush. The differences in these normalized yields between treated and untreated plots for each level of sagebrush abundance was then estimated and the increased forage produc-
Table 1. Forage Response (difference between controlled and uncontrolled sites) adjusted for differences between sites in seasonal precipitation and soil moisture (DM basis).

\begin{tabular}{|c|c|c|c|c|c|c|c|c|c|c|}
\hline \multirow[b]{2}{*}{ Year } & \multicolumn{10}{|c|}{ Co Sagebrush Canopy Cover } \\
\hline & $4 \%$ & $8 \%$ & $12 \%$ & $16 \%$ & $20 \%$ & $24 \%$ & $28 \%$ & $32 \%$ & $36 \%$ & $40 \%$ \\
\hline $1987^{1}$ & & & & & $V$ & ha & & & & \\
\hline 1988 & 17 & 50 & 83 & 116 & 150 & 183 & 216 & 249 & 282 & 315 \\
\hline 1989 & 124 & 157 & 190 & 223 & 256 & 289 & 322 & 356 & 389 & 422 \\
\hline 1990 & 230 & 263 & 297 & 330 & 363 & 396 & 529 & 462 & 495 & 528 \\
\hline 1991 & 337 & 370 & 403 & 436 & 469 & 502 & 536 & 569 & 602 & 635 \\
\hline
\end{tabular}

"Year of treatment. Grazing considered to be deferred and forage not utilized.

tion was assumed to be a function of treating the sagebrush. These regression adjusted differences are reported in Table 1.

\section{Economic Analysis}

Information needed to identify the economic threshold abundance level of big sagebrush includes the control methods to be analyzed and their associated costs, quantification of herbage responses and utilization associated with treatment, and valuation of the forage over the life of control.

\section{Control Methods and Associated Costs}

Several techniques are available for sagebrush control. Much of the earlier research looked at chemical control with 2,4-D. However, other methods of chemical control, as well as, burning and mechanical control are available to the land manager. Each one of these alternatives needs to be evaluated by the individual manager in terms of characteristics of the land, managerial objectives for the operation and economic feasibility.

Tebuthiuron has been found to control big sagebrush at the application rate of 0.6 to $1.1 \mathrm{~kg}$ a.i./ha by Whitson and Alley (1984). However, several drawbacks may exist with the use of tebuthiuron. Steinret and Stritzke (1977) found that phytotoxicity decreased forage production the first year after tebuthiuron application. Britton and Sneva (1983) found that mean herbaceous yields decreased with each increased rate of tebuthiuron. Bjerregaard et al. (1977) found forage yields were depressed for two years after application, but production increased later and the residual tebuthiuron showed potential for effective control against sagebrush seedlings for several years. Whitson and Alley (1984) observed that in the first year following application of tebuthiuron cool season grasses were chlorotic in appearance. However, reduced symptoms were noted in subsequent years.

Burning is an effective method for controlling sagebrush (Smith and Busby 1981). Mueggler and Blaisdell (1958) conclude that burning is by far the least expensive sagebrush control method despite the 1 year grazing deferment. Wambolt and Payne (1986) concluded that of 4 control methods, burning, spraying with $2,4-D$, rotocutting and plowing with seeding, burning was most effective in reducing sagebrush canopy. Plowing with seeding was found to be least effective. After 18 years burning provided the most production from dominant forage species and important vegetal classes, but burning and spraying were equally successful when production was totaled for all years sampled.

Shariff (1988) studied vegetation, soil moisture, and nitrogen responses with respect to 3 different methods used in controlling 
big sagebrush. This study compared 2,4-D, burning and tebuthiuron. Shariff concluded that the burn treatment exhibited the best response in the control of big sagebrush and total production. The 2,4-D treatment was found to be as effective as the burn treatment when the proper timing and application techniques were used. These conclusions concerning burning and spraying with 2,4-D are consistent with Hull and Klomp (1974). The tebuthiuron treatment appeared to be effective only on loamy soils.

In this study, spraying with $2,4-\mathrm{D}$ was the method of control used on the experimental units. For this analysis $\$ 26.54 / \mathrm{ha}^{2}$ is used as the chemical and application cost for 2,4-D. Given the findings of previous studies, this analysis also explores burning as a control method. According to data from the Soil Conservation Service average cost of burning in several Wyoming counties was estimated and adjusted for inflation to represent 1987 dollars. The estimated cost of burning used in this analysis was $\$ 13.73 / \mathrm{ha}^{3}$.

The burning scenario is only estimated for those experimental units which had enough biomass to sustain a burn. Smith et al. (1985) found when brush cover is below $30 \%$, fine fuel amounts must exceed approximately $333 \mathrm{~kg} / \mathrm{ha}$ (for continuous sod forming species) to near $667 \mathrm{~kg} / \mathrm{ha}$ (for discontinuous bunchgrass or rhizomatous wheatgrass species) for good fire spread to occur. If brush cover exceeds $30-35 \%$, fire spread will usually occur with lesser amounts of fine fuels. Given these criteria, those plots exhibiting 28 to $40 \%$ sagebrush cover were considered feasible for the bum scenario in this analysis.

One year of grazing deferment after treatment is assumed in this analysis. This is an additional cost associated with treatment which must be recaptured over the life of the control. An opportunity cost of not grazing that first year after treatment is calculated and added to the cost of treatment. The normalized yield data on the untreated plots for 1987 is multiplied by a $50 \%$ utilization rate and a conversion factor of $360 \mathrm{~kg}$ DM/AUM (Society for Range Management 1974, Scarnecchia and Kothmann 1982) to estimate animal unit months (AUM) of grazing forgone for each level of sagebrush abundance. The AUM's of grazing forgone is then multiplied by a net forage value of $\$ 6.13 /$ AUM to estimate the opportunity cost of deferment in the first year of treatment. The net lease rate of $\$ 6.13 / \mathrm{AUM}$ is an average of common lease rates for Wyoming during the years of 1981 to 1991 minus an estimate of $30 \%$ of the lease rate associated with services provided by lessors and adjusted to 1987 dollars (Wyoming Agricultural Statistics Service 1993, Torrell et al. 1988).

\section{Quantification of Herbage Response and Utilization}

Increased forage production resulting from sagebrush control lasts for varying periods. The longevity of control and amount of increased forage production varies from site to site and is influenced by degree of control. Johnson and Payne (1968) found that unkilled sagebrush was the major cause of reinvasion. Hull and Klomp (1974) found that killing the last $25 \%$ of a big sagebrush stand resulted in 98 to $135 \%$ more crested wheatgrass than killing the first $75 \%$ at southern Idaho sites.

In order to evaluate the feasibility of sagebrush control, the quantification of increased forage production must be estimated throughout the life of control for relevant planning horizons.

\footnotetext{
This based on commercial rates from Sky Aviation in Worland, Wyo. for 1987.

'This is based on personal phone interviews with personnel in the Cheyenne and Buffalo offices.
}

Kearl and Brannan (1967) used different figures for effective life of control depending on observed results for different methods. Chemical spraying with 2,4-D had a projected life of 15 years. Kearl and Freeburn (1983) found sites sprayed on National Forest land to be highly productive after 20 years. Tanaka and Workman (1988) used a planning horizon of 25 years for sagebrush control. Based on the literature and the sagebrush mortality on the experimental sites, 15 to 25 years is used as a reasonable planning horizon for the economic threshold analysis.

It is also important to understand long term trends in forage response, as well as utilization of forage to quantify the value of herbage response after sagebrush control. Blaisdell et al. (1982) discussed trends in sagebrush reinvasion and grass production after a controlled burn near Dubois, Ida. from 1936 to 1966. Much of the discussion was based on Harniss and Murray (1973). Over the 30 year period, mountain big sagebrush demonstrated a very dominant role in the plant community. During the first 12 years following burning, nearly all species of grasses, forbs and other shrubs increased in yield. In the subsequent 18 years following the burn, yields of the grasses, forbs and other shrubs decreased as sagebrush regained control. Forage production returned close to the preburn levels by the end of the 30 year period.

The economic analysis by Kearl and Freeburn (1983) assumed the usable forage production doubling in 2 years, forage production being sustained for years 3 through 10 and then forage production declining to the pretreatment levels in years 11 through 15. Jacobs (1987) used forage utilization by livestock to depict an increase in physical response due to sagebrush control. Jacobs assumed forage utilization to increase by $50 \%$ in year $2,100 \%$ in year 3 , sustained levels of utilization equal to year 3 in years 4 through 10 and forage utilization declining to pretreatment levels in years 11 through 15 .

Tanaka and Workman (1988) however, based the production function on the assumption that any increase in forage from an overstory treatment remained constant from the first year of grazing until the end of the project life. The production function values were adjusted for both desired utilization rate and availability of forage to livestock. The availability function was based on observations by Hull and Klomp (1974) and assumed to be linear between 40 and $90 \%$ as big sagebrush canopy varied from 34 to $0 \%$.

Workman and Tanaka (1991) illustrate several cases which suggest as utilization of forage increases and or sagebrush mortality decreases, reinvasion of sagebrush increases. In the first dynamic case illustrated by Workman and Tanaka (1991) a 50\% utilization rate and $95 \%$ initial overstory removal is assumed. This case resulted in a 20 year project life due to big sagebrush encroachment, while a $75 \%$ utilization rate and $95 \%$ mortality on sagebrush resulted in a 15 year project life. In the case where only $50 \%$ of the sagebrush were removed and $50 \%$ of the forage was utilized the projected life was 10 years.

Unfortunately, for this analysis only 4 years of forage response data is available for analysis (Table 1). Based on Blaisdell et al. (1982) and Harniss and Murray (1973) it seems reasonable to expect the forage response after sagebrush control to increase over a period of years and then decrease as sagebrush reinvades the treated area. It also seems reasonable based on the previous discussion to expect sagebrush control to last between 15 and 25 years. For this analysis, assumptions concerning the utilization of the forage are used to take into account a forage response curve. 
Increased forage utilization is based on the adjusted production data in Table 1 . One year of grazing deferment is assumed. It is also assumed that only $50 \%$ of the increased forage production is utilized annually and that $360 \mathrm{~kg} \mathrm{DM}$ provides 1 AUM. Maximum forage utilization increase is assumed to occur in year 4. It is further assumed that this level of utilization is maintained until year 10 . The increased forage utilization is assumed to decrease in equal increments after year 10 as sagebrush reinvades until the infestation reaches the pre-treatment level at the end of the specified planning horizon. Figure 1 illustrates the expected forage response versus the estimated forage utilization over the life of the control.

Valuation of the Forage and Estimate of Breakeven Price Over the Life of Control

Range managers may have different objectives for controlling sagebrush, and thus, different values may be placed on the increased forage production associated with treatment. Due to the unique characteristics of each individual situation, different values may need to be considered by a range manager. Workman (1986) discusses several possible approaches. One approach is to use a private lease rate. This "market value" approach is deemed reasonable because a manager would have an opportunity to lease these AUMs to stockmen if returns to the operation from the additional forage were less than the lease rate. Nielsen and Hinckley (1975) and Stevens and Godfrey (1976) used lease rate approaches to value additional forage from range improvements. Workman and Tanaka (1991) state that in many cases valuing revegetation benefits as privately leased forage is simple, straightforward and often yields accurate estimates of the value of additional forage particularly when the operation currently leases and or can avoid leasing forage in the future due to the improvement.

Private range lease rates, however, do have some caveats associated with valuing forage for an improvement. Jacobs (1987)

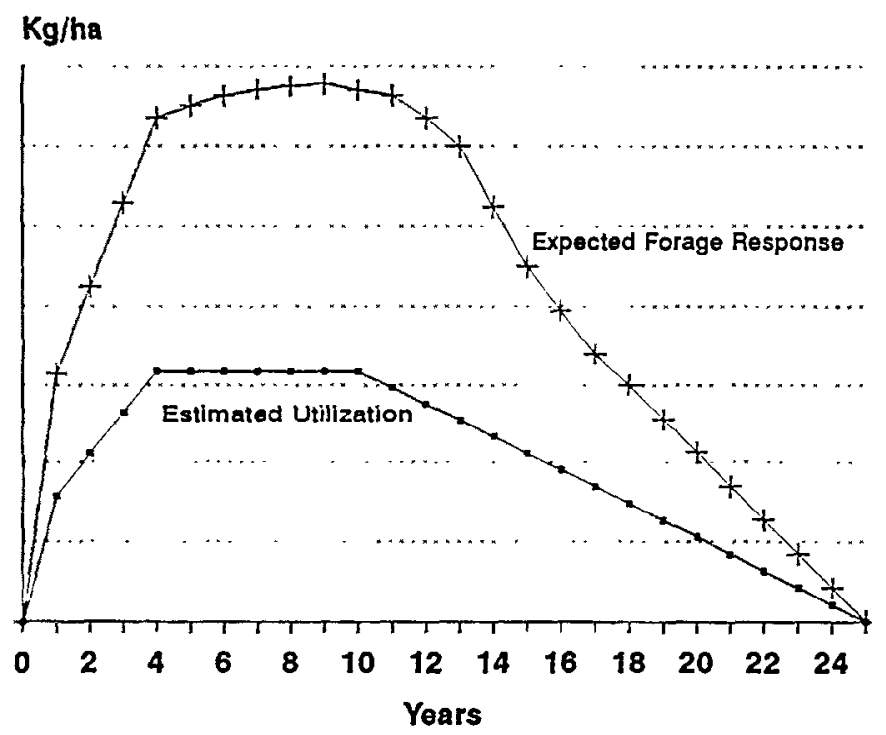

Fig. 1. Illustration of expected forage response curve versus estimated utilization based on assumptions used in the analysis. states that while some economists feel that grazing lease rates are a defendable value, they may tend to overestimate the value of forage for several reasons. One problem is lease rates may include a number of services as a premium (for example lessor may provide salt, fence repair, and herding). Workman and Tanaka (1991) report that published private lease rates include a premium for landlord services of about 30\% (Torell et al. 1988) and that the value of additional forage, itself, is only about $70 \%$ of published lease rates. A second problem according to Jacobs (1987) is that most grazing fees are based on short term leases. In many instances a producer would only consider variable costs when determining the maximum lease rate that would be feasible. Due to the short run nature of a lease "market value" of the forage could be higher than a long term arrangement where the fixed and variable costs are both considered. Workman and Tanaka (1991) note that pricing at the private lease rate often yields a higher revegetation benefit than does valuation as increased livestock production (Workman 1986).

Due to the possible shortcomings of grazing fees some economists prefer a total ranch budgeting approach when valuing additional forage from a range improvement. Nielsen (1967), Kearl and Freeburn (1983), and Tanaka and Workman (1988) all took a ranch budgeting approach. The general technique was to estimate additional ranch income due to the improvement. These additional income flows were then discounted back to present value and compared to the cost of the improvement. For a producer, a budgeting approach based on the specific requirements of the individual operation could offer more accurate information concerning the added profitability from a proposed improvement.

According to Workman (1986) ranch budgeting might also be used to calculate the average value of an added AUM. All nonforage costs can be subtracted from annual gross ranch income. The result of that calculation could then be divided by the total number of AUMs of forage used by the operation annually. This average value might then be used to do the analysis.

Perhaps the biggest advantage to a total ranch budget approach is this approach requires the manager to inventory all the resources available to the operation and decide whether the improvement can be done without creating a shortage elsewhere (Nielsen 1967). The producer may not want to increase spring grazing if the operation cannot meet the increased hay requirements brought on by increased stocking due to the improvement for example.

Unfortunately, the ranch budgeting approach is more complicated in terms of accounting for all resource inventories, valuing and planning the timing of resource usage and accurately reflecting all the effects of the improvement. Workman (1986) suggests the complexity of this approach is the biggest drawback. The ranch budgeting approach has some shortcomings for a researcher trying to make general recommendations concerning various improvements. The "typical case ranch" budget may be less representative of the intended audience of the research than a market value or lease rate approach. For this study, a large number of scenarios are investigated concerning initial sagebrush canopy cover levels, control methods and associated costs and different planning horizons for longevity of control, and the results are intended for a relatively broad audience of managers who might consider sagebrush control as an alternative. Thus, the ranch budgeting approach seems less desirable.

This economic analysis estimates the breakeven price the 
increased forage production must receive per AUM for each planning horizon, method of treatment and sagebrush abundance level to cover the initial cost of control and opportunity cost of deferment. The higher the breakeven price the less likely the range improvement will be feasible given the manager's objectives.

Since the investment in sagebrush treatment is not recaptured immediately, the returns associated with control must be discounted over the life of the control. Nearly all individuals display a positive time preference for money (Barry et al. 1983). A dollar received today is preferred to a dollar received a year from now. Thus, for an investment to be economically feasible, the sum of the future returns from the investment discounted to a present value must be greater than or equal to the initial cost of the investment.

The net present value (NPV) method uses discounting formulas to obtain the value of the projected cash flows associated with an investment alternative. In this fashion, the net present-value criterion directly accounts for the timing and magnitude of the projected cash flows for alternative investments having different planning horizons and cash flows. Given the concepts used in the net present value method, the following formula was derived and used to estimate the breakeven prices ( $\mathrm{PF}$ in formula) for this analysis. The PF (price of forage) value was solved for in an iterative fashion until NPV was equal to zero or as close to zero as possible without being negative.

$$
\operatorname{TRTCST}=\sum_{n=0}^{N}((\mathrm{UFF}) *(\mathrm{PF})) n
$$

Where:

$$
\begin{array}{ll}
\text { TRTCST } & =\text { Cost of treatment (including deferment). } \\
\text { UF } & =\text { Increase in utilizable forage due to treatment } \\
& \text { (converted to AUMs). } \\
\mathrm{i} & =\text { Discount rate. } \\
\mathrm{N} & =\text { Number of years in planning horizon. } \\
\mathrm{PF} & \text { Price of forage per AUM. } \\
((\mathrm{UF}) \%(\mathrm{PF}))_{\mathrm{n}} & =\text { The return received for each conversion period }
\end{array}
$$
(n) due to controlling sagebrush.

To express the value of the income flows in present terms they must be discounted at a relevant rate ( $\mathrm{i}$ in the above equation). Barry et al. (1983) state that for capital budgeting procedures the discount rate is a firm's required rate of return on its equity capital. The discount rate is generally considered to contain 3 components. There is a risk free rate for time preference, a rate reflecting the riskiness of the expected net cash flows and an inflation premium. The authors go on to state that the discount rate is much like an opportunity cost and should reflect a rate the firm's equity capital could earn in the most favorable alternative use.

Workman (1986) discusses criteria for picking a discount rate which are consistent with Barry et al. (1983). He states that ideally a discount rate should be the higher of either the interest rate on borrowed capital for the improvement or the opportunity cost rate. Given the best alternative use of range improvement capital is not always known, Workman (1986) suggests a representative borrowing rate is often used for discounting or comparison purposes. Generally since returns are measured in real terms, the appropriate discount rate should be in real terms as well.

For this analysis a discount rate of $6 \%$ was chosen. This was based on a long term (1950 to 1992) average real prime interest rate of $3 \%$ (U.S. Government Printing Office 1993) plus a 3\% risk premium. Tanaka and Workman (1988) used a 7\% discount rate, using a $4 \%$ rate plus a $3 \%$ risk premium. The higher the dis- count rate the larger breakeven price of the forage would have to be over the life of control to cover the initial cost of control plus the opportunity cost of deferment. For example, if the maximum increase in forage utilization was based on an increase of 232 $\mathrm{kg} / \mathrm{ha}$ in year 4 using 2,4-D and with a 20 year expected longevity, the average value of the increased forage or breakeven price would have to be $\$ 11.08 / \mathrm{AUM}$ to cover the cost of treatment at a $6 \%$ discount rate. At a $7 \%$ discount rate, assuming everything else remained the same, the price of the forage would have to be $\$ 11.92 / A U M$, and if a $10 \%$ discount rate were used, the breakeven return for the forage would increase to $\$ 14.82 / \mathrm{AUM}$.

These estimated breakeven forage prices (PF) must be compared to estimates of what that forage is actually worth before conclusions can be drawn about which initial sagebrush abundance level could be considered as economically feasible to control. As mentioned earlier, one problem with private grazing leases is the lease rate may include a number of services (for example, salting, fence repair, and herding). Thus, a net lease rate which has these types of services subtracted out may more accurately reflect the value of forage. A net lease rate of $\$ 6.13 / \mathrm{AUM}$ is used as an estimate for comparison in this analysis. Conclusions concerning the economic threshold level of big sagebrush are drawn by comparing this inflation adjusted value less services to the estimated breakeven prices for each scenario.

\section{Results}

A breakeven return per AUM has been calculated for each sagebrush abundance level, life of control and treatment method scenario $(2,4-D$, burn) with only half of the increased forage production assumed to be available for grazing after 1 year of deferment (Fig. 2). The return per AUM represents what the increased forage production must receive annually over the life of control in order to equal the sum of the cost of the treatment and opportunity cost of deferment.

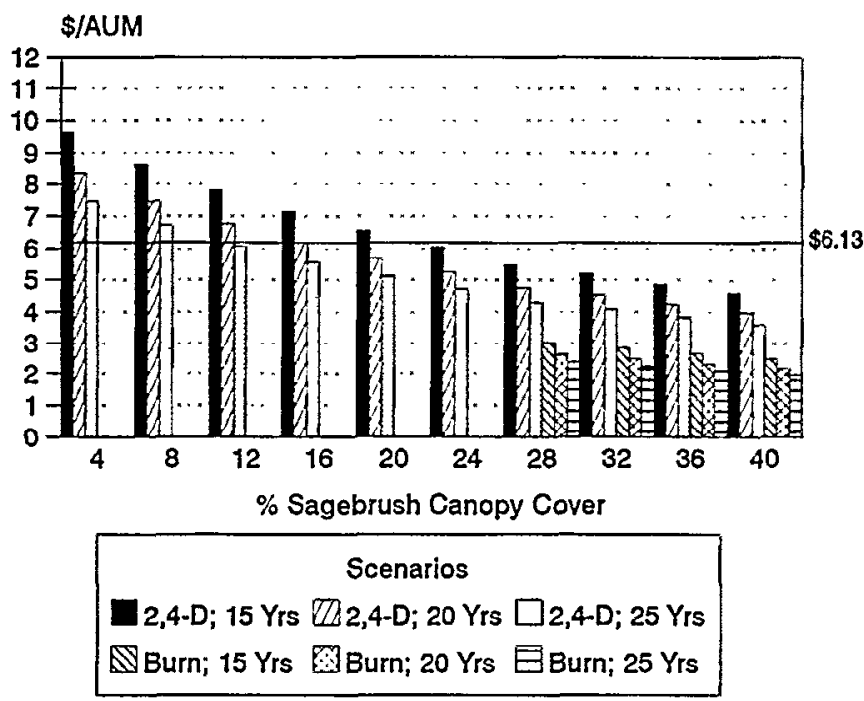

Fig. 2. Breakeven return per AUM needed to cover treatment cost and deferment under various scenarios of control method and expected life of control. 
The breakeven return per AUM for increased forage production from various scenarios of sagebrush control ranges from a high of $\$ 9.66 / \mathrm{AUM}$ to a low of $\$ 1.95 / \mathrm{AUM}$. The high occurs at the $4 \%$ sagebrush abundance level, assuming a 15 year life of control and spraying with $2,4-\mathrm{D}$ as the control method. The low of $\$ 1.95 /$ AUM occurs at the $40 \%$ sagebrush abundance level, assuming a 25 year life of control and burning as the control method. The breakeven return per AUM needed to cover the treatment cost decreases as the life of control increases (Fig. 2). This is expected since more total forage can be utilized the longer the treatment lasts. Given the cost of burning is assumed to be about half that of 2,4-D, it is no surprise that the breakeven returns required per AUM in the burn scenarios for the 28 to $40 \%$ sagebrush abundance levels are almost half that of spraying with 2,4-D. The other general conclusion which can be drawn from Figure 2 is the relationship of the initial sagebrush abundance level and the breakeven return per AUM. The lower the sagebrush infestation level, the less increase in forage production (Table 1) and the higher the return per AUM of forage must be to cover the investment in control.

If $\$ 6.13 / \mathrm{AUM}$ is a reasonable value to place on forage, the $12 \%$ sagebrush scenario becomes feasible if the control lasts 25 years, $2-4, D$ is the control method, forage response is at least the amount reported in Table 1 and utilization assumptions used in this analysis are met (Fig. 2). At the $24 \%$ sagebrush level all 3 longevity of control scenarios become feasible. Since burning is assumed to cost almost half of the 2,4-D treatment all of the burn scenarios are economically feasible if $\$ 6.13 /$ AUM is the value placed on forage (Fig. 2).

\section{Discussion and Conclusions}

Given $\$ 6.13 /$ AUM is a representative value for forage, the economic threshold level for control occurs within a broad range of sagebrush abundance levels ( 12 to $24 \%$ cover) depending on life of the control and forage response. As the cost of control increases, the initial abundance level and corresponding production response must be higher before control becomes economically feasible. As the longevity of control increases relatively less production response is needed to make sagebrush control feasible.

Although the results of this analysis are meant to be generally applicable to a wide readership, it is important to keep in mind the limitations of this study. This analysis involved data from an experiment in Carbon County, Wyo. The results of this experiment could be site specific. No other studies in native vegetation report forage responses associated with different initial sagebrush abundance levels. Thus, the production responses used in the analysis may not be representative of other areas which might benefit from big sagebrush control.

Another limitation of this analysis stems from the projections used to estimate increased forage utilization over the life of control given response data for a limited number of years. Results from Blaisdell et. al (1982) and others indicate forage response would tend to peak later than year 4 . This might suggest the analysis is conservative in estimating total possible forage utilization over the life of the control.

An additional consideration is that the economic analysis in this study assesses only the added benefits and costs associated with controlling big sagebrush. A manager may want to do a more complete budget that takes into account all the characteristics of this type of improvement which are unique to the operation and manager's objectives before controlling sagebrush. However, we do identify some of the major considerations and outline a framework for the economic analysis, as well as provide a general indication of the sagebrush abundance and forage responses needed before big sagebrush control enters the realm of economical feasibility.

\section{Literature Cited}

Alley, H.P. 1965. Big sagebrush control. Wyoming Agr. Exp. Sta. Bull. 345R. Laramie, Wyo.

Alley, H.P. 1956. Chemical control of big sagebrush and its effect upon production and utilization of native grass species. Weeds. 4:164-173.

Alley, H.P. and D.W. Bohmont. 1958. Big sagebrush control. Wyoming Agr. Exp. Sta. Bull. 345. Laramie, Wyo.

Barry, P.J., J.A. Hopkin and C.B. Baker. 1983. Financial management in agriculture. 3rd ed. The Interstate Printers \& Publishers, Inc., Danville, Ill.

Bartolome, J.W. and H.F. Heady. 1978. Ages of big sagebrush following brush control. J. Range Manage. 31:403-11.

Bjerregard, R.S., J.A. Keaton, K.E. McNeill and W.C. Warner. 1978. Rangeland and brush and weed control with tebuthiuron. Proc. First Int. Rangeland Congr. of the Society for Range Manage. 1:654-56.

Blaisdell, J.P., R.B. Murray and E.D. McArthur. 1982. Managing intermountain rangelands: sagebrush-grass ranges. Gen. Tech. Rep. INT-134. USDA Intermountain Forest and Range Exp. Sta., Ogden, Ut.

Britton, C.M. and F.A. Sneva. 1983. Big sagebrush control with tebuthiuron. J. Range Manage. 36:707-08.

Clary, W.P., S. Goodrich and B.M. Smith. 1985. Response to tebuthiuron by Utah juniper and mountain big sagebrush communities. J. Range Manage. 38:56-60.

Environmental Protection Agency. 1972. Pesticides Study Series - 3, The use and effects of pesticides for rangeland sagebrush control. Office of Water Programs, Washington, D.C..

Harniss, R.O. and R.B. Murray. 1973. Thirty years of vegetal change following burning of sagebrush-grass range. J. Range Manage. 26:320-25.

Hull, A.C. Jr., N.A. Kissinger Jr., and W.T. Vaughn. 1952. Chemical control of big sagebrush in Wyoming. J. Range Manage. 5:398-402.

Hull, A.C. Jr. and G.J. Klomp. 1974. Yield of Crested Wheatgrass under four densities of Big Sagebrush in southern Idaho. USDA-ARS. Tech. Bull. 1483. Washington, D.C.

Jacobs, J.J. 1987. Time and data needs in the economic analysis of range management decisions, p. 49-55, J.A. Onsager, Editor. Integrated Pest Management on Rangeland. USDA Bull. ARS-50, USDA Agr. Res. Ser.. Washington, D.C., :49-55.

Johnson, J.R. and G.F. Payne. 1968. Sagebrush reinvasion as affected by some environmental intluences. J. Range Manage. 2I:209-13.

Kearl, W.G. and M. Brannan. 1967. Economics of mechanical control of sagebrush in Wyoming. Wyoming Agr. Exp. Sta. Science Monogr. 5. Laramie, Wyo.

Kearl, W.G. and J.W. Freeburn. 1983. Economics of big sagebrush control for mitigating reductions of federal grazing permits. Wyoming Agr. Exp. Sta. Bull. AE 80-05-2R. Laramie, Wyo.

Kearl, W.G. 1965. A survey of big sagebrush control in Wyoming, 1952-64. Wyoming Agr. Exp. Sta. Bull. M.C. 217. Laramie, Wyo.

Krenz, R.D. 1962. Costs and returns from spraying sagebrush with 2,4-D. Wyoming Agr. Exp. Sta. Bull. No. 390. Laramie, Wyo.

Miller, R.F., R.R. Findley and J. Alderfer-Findley. 1980. Changes in mountain big sagebrush habitat type following spray release. J. Range Manage. 33:278-81.

Mueggler, W.F. and J.P. Blaisdell. 1958. Effect on associated species of burning, roto-beating, spraying and railing sagebrush. J. Range Manage. 11:61-66.

Nielsen, D.B. and S.D. Hinckley. 1975. Economic and environmental impacts of sagebrush control on Utah's rangelands: a review and analysis. Utah Agr. Exp. Sta. Bull. No. 25. Logan, Ut.

Nielsen, D.B. 1967. Economics of range improvements: a rancher's handbook to economic decision making. Utah Agr. Exp. Sta. Bull. No. 466. Logan, Ut. 
Pechanec, J.F., G. Stewart, A.P. Plummer, J.H. Robertson and A.C. Hul Jr. 1954. Controlling sagebrush on rangelands. USDA Farmer's Bull. No. 2072, Washington D.C., United States Govt. Printing Office.

Sala, O.E., W.J. Parton, L.A. Joyce and W.K. Lauenroth. 1988. Primary production of the central grassland region of the United States. Ecology. 69:40-45.

Scarnecchia, D.L. and M.M. Kothmann. 1982. A dynamic approach to grazing management terminology. $J$. Range Manage. 35:262-64.

Shariff, A.R. 1988. The vegetation, soil moisture and nitrogen responses to three big sagebrush (Artemisia tridentata Nutt.) control methods. M.S. Thesis, Univ, of Wyoming, Laramie, Wyo.

Society for Range Management. 1974. A glossary of terms used in range management. 2nd. ed.

Steinret, W.G. and J.F. Stritzke. 1977. Uptake and phytotoxicity of tebuthiuron. Weed Sci. 25:390-95.

Stevens, J.B. and E.B. Godfrey. 1976. An economic analysis of public range improvements on the Vale project, 1960-69. Oregon Agr. Exp. Sta. Circ. No. 653. Corvallis, Ore.

Smith, M.A., J.L. Dodd and J.D. Rodgers. 1985. Prescribed burning on Wyoming rangeland. Wyoming Agr. Ext. Serv. Bull. 810. Laramie, Wyo.

Smith, M.A. and F. Busby. 1981. Prescribed burning: effective control of sagebrush in Wyoming. Wyoming Agr. Exp. Sta. Bull. RJ-165. Laramie, Wyo.

Sturges, D.L. 1986. Responses of vegetation and ground cover to spraying a high elevation, big sagebrush watershed with 2,4-D. J. Range Manage. 39:141-46.
Tabler, R.D. 1959. The root system of Artemisia tridentata. Ecology. 45:63336.

Tanaka, J.A. and J.P. Workman. 1988. Economic optimum big sagebrush control for increasing crested wheatgrass production. J. Range Manage. 41:172-77.

Torrell, L.A., S. Ghosh and J.M. Fowler. 1988. Economic considerations for setting grazing fees on New Mexico State trust lands. New Mexico Agr. Exp. Sta. Special Rep. No. 81. Las Cruces, N.M.

United States Govt. Printing Office. 1993. Economic report of the President: transmitted to the congress January 1993 together with the annual report of the council of economic advisers. Washington, D.C.

Wambolt, C.L. and G.F. Payne. 1986. An 18-year comparison of control methods for Wyoming big sagebrush in southwestem Montana. J. Range Manage. 39:314-19.

Whitson, T.D. and H.P. Alley. 1984. Tebuthiuron effects on Artemisia spp. and associated grasses. Weed Sci. 32:180-84.

Whitson, T.D. and H.P. Alley. 1982. Effects of tebuthiuron on range species complex and forage production. Proc. West. Society of Weed Sci. 35:3941 .

Workman, J.P. and J.A. Tanaka. 1991. Economic feasibility and management considerations in range revegetation. J. Range Manage. 44:566-72.

Workman, J.P. 1986. Range economics. Macmillan Publishing Company, N.Y.

Wyoming Agricultural Statistics Service. 1993. Wyoming agricultural statistics 1992. Wyoming dept. Agr., Cheyenne, Wyo. 